\title{
Screening for production of amylase and protease by locally-isolated Bacillus spp. from soil collected in Taguig City and Clark Freeport Zone, Philippines
}

\author{
John Paul Matthew Guzman ${ }^{12 *}$, Sheila Mantaring1, Elizabeth Panerio ${ }^{1}$ \\ 1 Industrial Technology Development Institute, Department of Science and Technology, Bicutan, Taguig City, Philippines \\ The Graduate School, University of Santo Tomas, España, Manila, Philippines
}

\begin{abstract}
Amylase and protease are two of the most commonly used enzymes in the pharmaceutical industry. Particularly, Bacillus spp. is widely regarded as a "factory" of these enzymes. In this study, a total of 40 isolates were collected from four soil samples from different metropolitan sites namely, near Chemicals and Energy Division (CED), and National Metrology Laboratory (NML) oil tankers parking lot inside the Department of Science and Technology (DOST) Compound in Taguig City, and two metropolitan-volcanic sites in Clark Freeport Zone, Pampanga (CRK1, CRK2). Of these, 33 isolates were deemed putative Bacillus spp. via phenotypic assays and were screened for the production of amylase and protease. Results showed that 26 of the screened isolates were able to produce protease and 12 were positive for amylase production. Molecular identification revealed that the enzyme-producing isolates were Bacillus spp., B. cereus, B. aryabhattai, B. amyloliquefaciens, B. firmus, B. velezensis, and Fictibacillus sp. No isolate was able to produce amylase alone. These results show the potential of Bacillus spp. from metropolitan soil as sources of pharmaceutically-important enzymes.
\end{abstract}

Keywords:

Amylase, Bacillus spp., Enzyme production, Metropolitan soil, Protease, Volcanic soil

\section{INTRODUCTION}

Microbial enzymes are increasingly being favored due to their being relatively easier to produce compared with other sources ${ }^{1}$. Owing to their conditions, soils harbor a diverse plethora of microbial species, thereby resulting in a wide range of enzymes with varying characteristics ${ }^{2}$. Among these species, the genus Bacillus has been widely regarded as "factory" of different bioactive compounds including enzymes ${ }^{3}$. Some of the commonly produced enzymes of Bacillus sp. with pharmaceutical importance are amylases and protease ${ }^{4-5}$.

Amylases are enzymes that catalyze the cleavage of glycosidic bonds of $\operatorname{starch}^{6}$. Hence, they are typically used in food processing and bioremediation ${ }^{1}$. Because of their activity, amylases are also widely used for pharmaceutical purposes such as for the treatment of calorie deficiency and as digestive tonics ${ }^{6-7}$. On the other hand, proteases are enzymes that hydrolyze the peptide bonds in polypeptides. These enzymes are commonly used in the waste management, food and feed processing, and other industries ${ }^{8}$. In the field of pharmacy, proteases are used in the treatment of various communicable and non-communicable diseases ${ }^{9}$.

Changes in the conditions of the soil alter the production and stability of microbial enzymes ${ }^{10}$. These changes may be brought about by several factors from the continuous and rapid urban development ${ }^{11}$, to changes as drastic as volcanic eruptions ${ }^{12}$. Hence, in this study, microbial amylases and proteases produced by Bacillus sp. isolated from soils collected in highly-urbanized areas, with one having experienced a volcanic eruption in the past ${ }^{13}$ were screened.

\section{*Corresponding author:}

*John Paul Matthew Guzman Email: jpmdguzman@itdi.dost.gov.ph

Pharmaceutical Sciences Asia (C) 2022 by

Faculty of Pharmacy, Mahidol University, Thailand is licensed under CC BY-NC-ND 4.0. To view a copy of this license, visit https:// www.creativecommons.org/licenses/by-nc-nd/4.0/ 


\section{MATERIALS AND METHODS}

\subsection{Collection of soil samples}

Approximately $250 \mathrm{~g}$ of 2 - to 5 -cm-deep surface soil samples were collected from two sites in the Department of Science and Technology (DOST) Compound, Bicutan, Taguig City: (1) near the Chemicals and Energy Division (CED) Building (14²9'29.0"N 121 $\left.03^{\circ} 10.0^{\prime \prime} \mathrm{E}\right)$ and (2) at the National Metrology Laboratory (NML) oil tankers calibration site $\left(14^{\circ} 29^{\prime} 24.1^{\prime \prime} \mathrm{N} 121^{\circ} 03^{\prime} 05.2^{\prime \prime E}\right)$. These two locations were selected due to their being situated in Metro Manila, and the heavy foot and vehicular traffic in these areas. Furthermore, a pilot plant for chemicals production is situated in proximity with the CED sampling site, and oil tankers are being calibrated at the NML sampling site. Similarly, soil samples were also collected from two sites in Clark Freeport Zone,

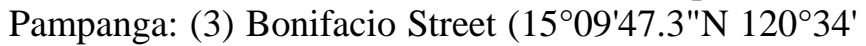
20.6"E) and (4) Sarmiento Street (15 $09^{\prime} 45.3^{\prime \prime N} 120^{\circ} 34^{\prime}$ $21.8^{\prime E}$ ). The Clark Freeport Zone is among the areas in Northern Luzon which was directly affected by the 1991 Mt. Pinatubo eruption ${ }^{14}$. All four soil samples were stored in sterile, resealable plastic bags for immediate transport to the laboratory. The temperature and relative humidity $(\mathrm{RH})$ of the sampling sites were also noted.

\subsection{Isolation of putative Bacillus spp.}

Twenty-five grams of each soil sample was first homogenized in $250 \mathrm{~mL} 0.1 \%$ peptone water (PW). Thereafter, serial dilution up to $10^{-4}$ was performed. Each dilution was spread on Mannitol-Yolk-Polymyxin B (MYP) agar and incubated at $35^{\circ} \mathrm{C}$ for $24 \mathrm{~h}^{15}$. Dilutions with growths within the valid count (30-300 colonies) were selected for isolation. Putative Bacillus spp., which were selected based on their morphologies, were isolated by streaking each colony on Tryptone Soya Agar (TSA) until pure cultures were obtained. The isolates were stored at $4^{\circ} \mathrm{C}$ until further use.

\subsection{Screening for enzyme production}

\subsubsection{Amylase production}

Each isolate was streaked on starch agar and incubated for $24 \mathrm{~h}$ at $35^{\circ} \mathrm{C}$ to screen for amylase activity. A clearing zone observed upon flooding with iodine indicated amylase activity ${ }^{4}$.

\subsubsection{Protease production}

Each isolate was streaked on TSA supplemented with $10 \%$ skim milk and incubated for $24 \mathrm{~h}$ at $35^{\circ} \mathrm{C}$ to screen for protease activity. An isolate showing a clearing zone indicated protease activity ${ }^{16}$.

\subsection{Phenotypic and genotypic identification}

Colony morphologies of the isolates on TSA plates were noted and Gram staining was performed to characterize their cellular morphologies. Biochemical characterization including catalase test and sugar fermentation were also conducted.

The genomic DNA (gDNA) of putative Bacillus spp. isolates were extracted using ISOLATE II Genomic DNA extraction kit (Bioline, USA). Thereafter, the gDNA were subjected to Polymerase Chain Reaction (PCR) using the MyTaq Red HS PCR Mix (Bioline, USA) to amplify the 16S rRNA gene using the primers $27 \mathrm{~F}$ (5'AGAGTTTGATCMTGGCTCAG-3') and 1492R (5'TACGGYTACCTTGTTACGACTT-3'). Amplicons were run on $1 \%$ agarose gel electrophoresis for verification. Amplicons were sent to Macrogen, Korea for capillary sequencing. The sequences were analyzed using NCBI BLASTn and phylogenetic trees were constructed using Maximum Likelihood Method via the BioEdit software.

\section{RESULTS AND DISCUSSION}

\subsection{Putative Bacillus spp. were isolated from soil samples from different localities}

Forty isolates were obtained upon plating each of the soil samples from all four sites on MYP agar (Figure 1). Fifteen of which were from soil collected near the CED Building and eight from the parking lot for oil tankers near the NML Building at the DOST Compound, Taguig City. Eight isolates were collected from soil samples from Bonifacio Street (CRK1), and nine from Sarmiento Street (CRK2) in Clark Freeport Zone, Pampanga. During the time of collection, the atmospheric
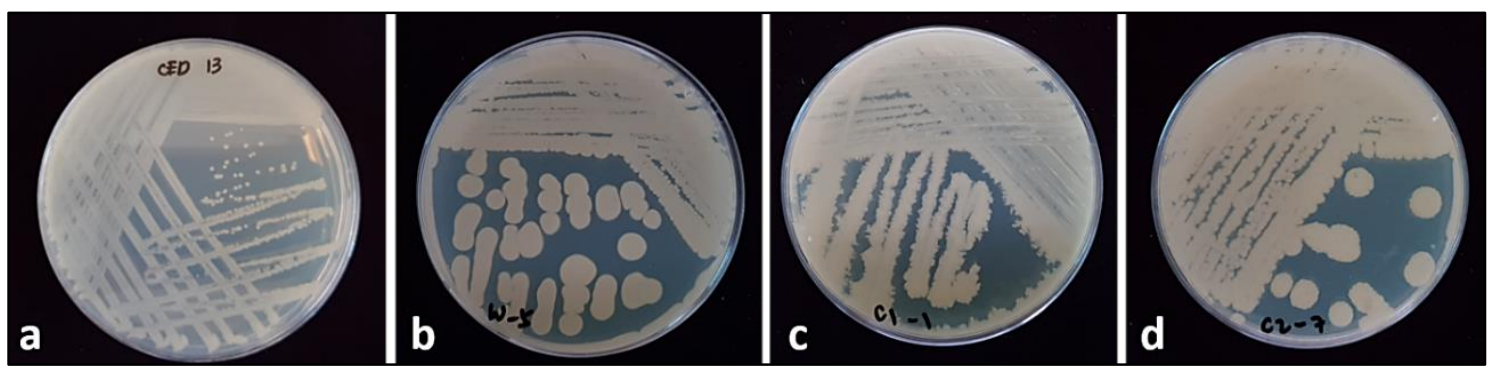

Figure 1. Representative plates showing putative Bacillus spp. isolates from (a) CED, (b) NML, (c) CRK1, and (d) CRK2 soil samples. 
conditions were around $32^{\circ} \mathrm{C}, 56 \% \mathrm{RH}$, and $29^{\circ} \mathrm{C}, 77 \%$ $\mathrm{RH}$, respectively. Whereas, edaphic temperature of the soil samples was around $21-24^{\circ} \mathrm{C}$.

Based on their phenotypic characterization, 33 isolates were deemed to be putative Bacillus spp., showing Gram-positive rods and testing positive for catalase activity (Figure 2), and were thus selected for the succeeding screening for the enzyme production.

\subsection{Locally-isolated putative Bacillus spp. produce pharmaceutically-important enzymes}

Changes in edaphic conditions facilitate the dynamics of soil microbial ecology, and affect the enzymes produced by microorganisms in soil ${ }^{10}$. More specifically, urbanization has caused drastic changes in soil conditions ${ }^{11}$. In this study, the 33 putative Bacillus spp. isolates from soil samples from two different metropolitan areas in the Philippines were screened for their enzyme production. A total of 14 isolates from CED (Table 1), six from NML (Table 2), four from CRK1 and two from CRK2 (Table 3) were observed to produce enzymes based on phenotypic assays (Figure 3). Of these, 12 isolates produced amylase, while 26 had protease activity.

Amylases are enzymes that catalyze the hydrolysis of starch via the cleavage of its glycosidic bonds, thereby yielding shorter oligosaccharides as a result. Because of this enzymatic function, it is involved in the digestion of food ${ }^{6}$. Amylases of microbial origin have been observed, and are used in industrial-scale production $^{17}$. Because of this, its use in the pharmaceutical industry has become extensive, particularly as digestive tonics ${ }^{7}$, for enzyme replacement therapy ${ }^{18}$, and as treatment for calorie deficiency ${ }^{6}$, to name a few. Among all microbial sources, Bacillus spp. have the most extensive

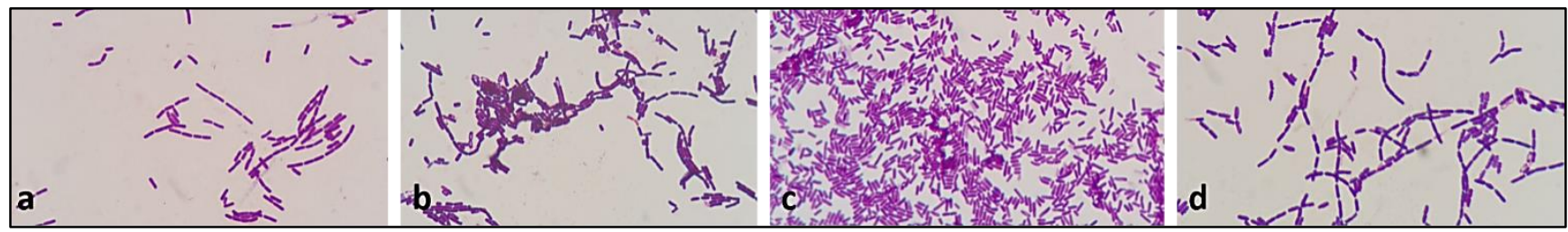

Figure 2. Representative microscopy images of Gram-stained putative Bacillus spp. isolates from (a) CED, (b) NML, (c) CRK1, and (d) CRK2 soil samples.

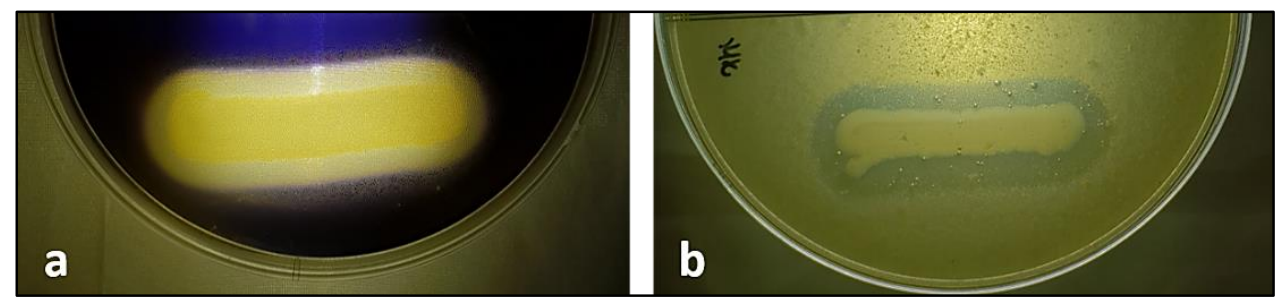

Figure 3. Representative plates showing (a) amylase and (b) protease production.

Table 1. Screening for enzyme production of putative Bacillus spp. isolated from CED soil sample.

\begin{tabular}{|c|c|c|c|c|c|c|c|c|c|c|c|c|c|c|}
\hline \multirow{3}{*}{ Enzyme } & \multicolumn{14}{|c|}{ Isolates } \\
\hline & CED & CED & CED & CED & CED & CED & CED & CED & CED & CED & CED & CED & CED & CED \\
\hline & 1 & 2 & 3 & 4 & 5 & 6 & 7 & 9 & 10 & 11 & 12 & 14 & 15 & 16 \\
\hline Amylase & + & - & + & + & - & - & - & + & + & - & - & + & + & + \\
\hline Protease & + & + & + & + & + & + & + & + & + & + & + & + & + & + \\
\hline
\end{tabular}

Table 2. Screening for enzyme production of putative Bacillus spp. isolated from NML soil sample.

\begin{tabular}{ccccccc}
\hline Enzyme & \multicolumn{9}{c}{ Isolates } \\
\cline { 2 - 7 } & W2 & W3 & W4 & W5 & W8 & W9 \\
\hline Amylase & + & - & - & - & + & + \\
Protease & + & + & + & + & + \\
\hline
\end{tabular}

Table 3. Screening for enzyme production of putative Bacillus spp. isolated from CRK1 and CRK2 soil samples.

\begin{tabular}{cccccccc}
\hline Enzyme & \multicolumn{9}{c}{ Isolates } \\
\cline { 2 - 7 } & CRK1-1 & CRK1-3 & CRK1-5 & CRK1-8 & CRK2-5 & CRK2-7 \\
\hline Amylase & - & + & + & + & + & + & + \\
Protease & + & + & + & + & + & + \\
\hline
\end{tabular}


amylase production ${ }^{17}$.

Out of the 12 isolates observed to produce amylase, eight were from CED (Table 1), and two were from NML soil samples (Table 2). Variations in the number of isolates found to produce amylase might be the effect of the changed edaphic conditions brought about by urbanization in these areas ${ }^{11}$. Meanwhile, only one from each of the two CRK samples (Table 3) was observed to produce amylase. It is noteworthy that the area where these samples were collected is now a highlyurbanized area after experiencing an intense volcanic eruption in the past ${ }^{14}$. Previous studies have shown that volcanic eruptions drastically change the conditions of the soil, particularly by introducing heavy metals ${ }^{12,19}$. These changes significantly decrease enzymatic activities in soil ${ }^{20-22}$. Interestingly, amylase-producing isolates were still collected from the soil samples in this study. Perhaps this is due to the subsequent changes in soil conditions brought about by urbanization in the area post-eruption.

In this study, all screened isolates were able to produce protease (Table 1-3). The high number of isolates capable of producing protease is expected since the samples where they were isolated are soils which are high in minerals (usually in organic form). Proteases are capable of hydrolyzing proteins which results in the availability of free nitrogen for plants. Thus, this enzyme is important in the nitrogen cycle in soils. In the pharmaceutical industry, proteases are incorporated in solutions for bandages, gauzes, among others, for the treatment of wounds and burns ${ }^{8}$. Furthermore, proteases are also used in therapeutics, particularly in the treatment of cardiovascular diseases, inflammation, and even infectious diseases ${ }^{9}$. Interestingly, similar to amylase, Bacillus spp. are considered to be the most widely-used in the production of proteases ${ }^{8}$.

It is noteworthy that while all screened isolates were able to solely produce protease, no isolate was able to produce amylase alone (Tables 1-3). This result is similar to a previous study wherein the authors also observed that no isolate was able to produce only amylase $^{1}$. Moreover, they have also isolated strains which were able to produce only one of the enzymes tested. They argued that this may be because the specific substrate of the enzyme is important in the metabolism of the microbial cell. Furthermore, the ability of the isolates to produce two or more enzymes suggests that there might be synergistic activities between these enzymes on the overall metabolism of the cell. Hence, co-production of these two enzymes is being pursued ${ }^{2-3}$. These also suggest that the isolates from this study which were able to produce both enzymes may be tapped in the co-production of amylase and protease. Optimization studies on the enzyme production of these isolates may be pursued to exploit these capabilities.

\subsection{Enzyme-producing isolates identified as Bacillus spp. and Fictibacillus sp. via 16S rRNA amplification and phylogenetic analyses}

Isolates which were observed capable of producing any of the two selected enzymes were subjected to molecular identification. In this study, $79 \%$ of all the isolates tested were observed to produce enzymes (Table 1) and were identified as Bacillus spp. This genus is increasingly being favored as a "factory" of different industrially-important compounds such as enzymes due to their safety as well as their capability to produce large amounts of proteins ${ }^{4}$. Particularly, Bacillus spp. are considered to be the most widely-used bacteria in the production of both amylase and protease ${ }^{5-6}$.

Twelve of the isolates from CED soil were identified as Bacillus spp., and two were B. cereus based on sequence similarities (Figure 4), whereas, enzymeproducing isolates obtained from soil collected from the NML oil tankers parking lot were identified as Bacillus spp., B. cereus, B. aryabhattai, B. firmus, and Fictibacillus sp. (Figure 5). Meanwhile, B. cereus, B. aryabhattai and $B$. velezensis were the identities of the isolates from CRK1 and CRK2 samples. The differences in terms of species diversity in the soil samples may be due to their respective edaphic conditions, particularly with the variations brought about by urbanization, and in the case of CRK samples, volcanic eruptions ${ }^{7-10}$.

Of particular interest with these results is that amylase production is observed only in the isolates identified as Bacillus spp. and B. cereus. Previous reports of these species isolated from various soil and hotspring samples in the Philippines have similarly showed their capabilities to produce amylase ${ }^{11}$. However, it is recommended that a more in-depth genotypic characterization be performed to identify the Bacillus spp. isolates up to the species level. Nonetheless, amylase production was also observed in both the metropolitan (CED, NML) and metropolitan-volcanic (CRK1, CRK2) samples.

Volcanic eruptions result in the introduction of heavy metals in soil, hence changing the overall edaphic conditions ${ }^{9}$. As a result, microbial ecology as well as their enzyme production are also affected ${ }^{7}$. In the CRK samples, B. cereus were identified as the sole producers of amylase. Perhaps, the persistence of B. cereus may be attributed to their reported capabilities to tolerate and even remediate heavy metals in soil ${ }^{12-13}$.

In the case of protease, the identified isolates were more diverse. B. cereus was also identified in a number of isolates from all four samples (Figures 4-6). This species has been previously reported to produce protease $^{14-16}$. Two isolates from NML (W3, W5) and one from CRK2 (CRK2-7) were identified as B. aryabhattai (Figures 5-6). It is a plant-growth promoting species first isolated in cryotubes used for air sampling ${ }^{17-18}$. There are very few reports on enzyme production by $B$. aryabhattai, 

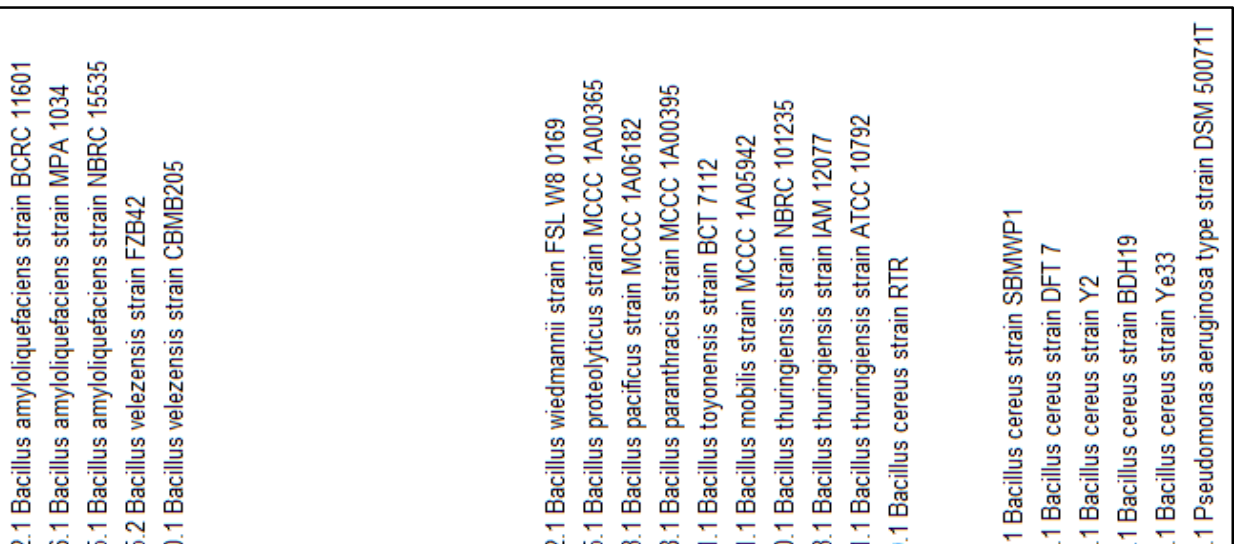

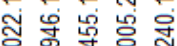

-

罂

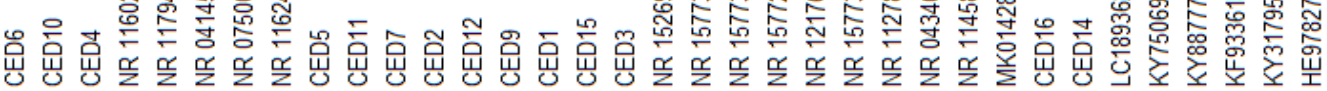

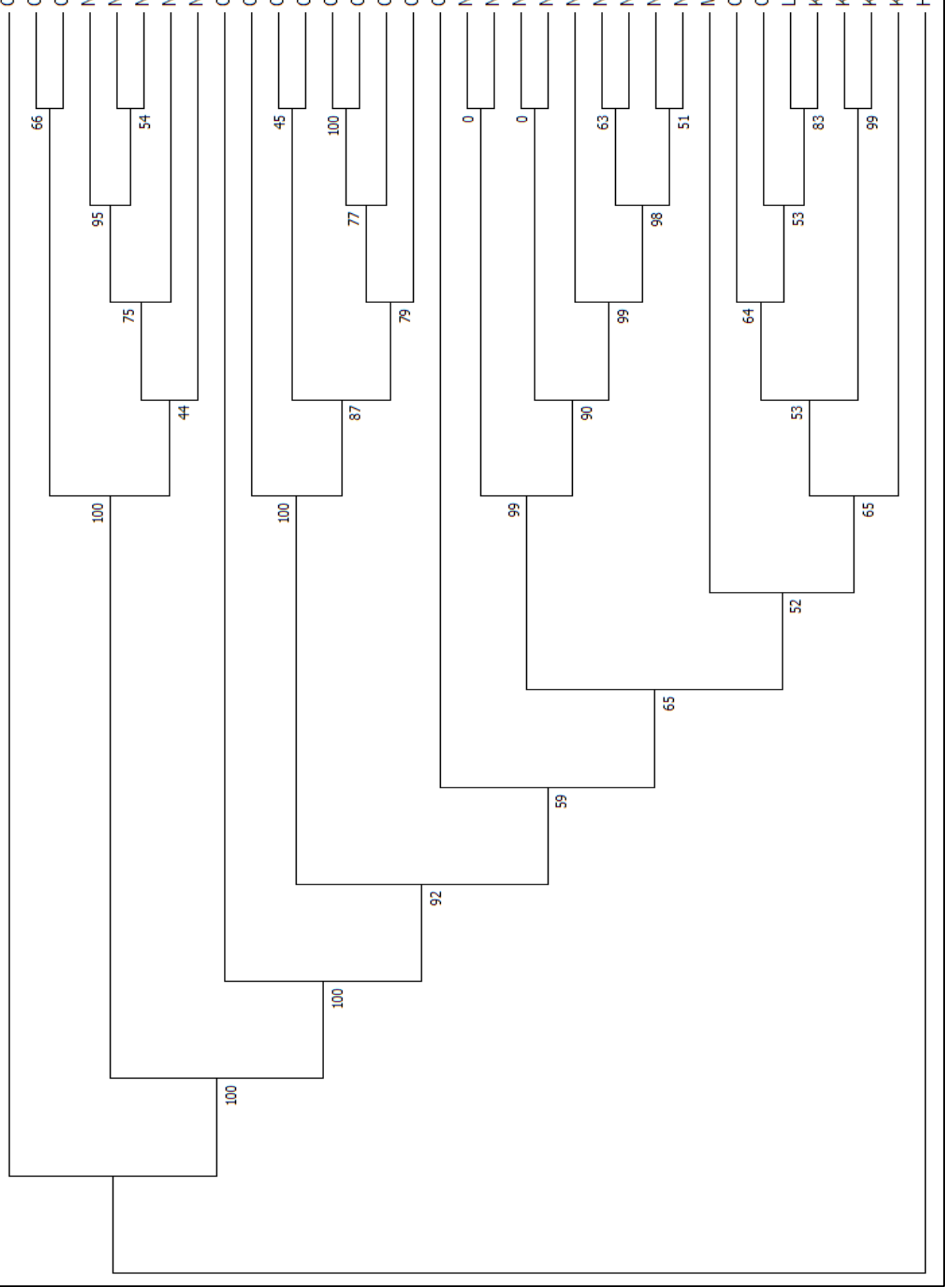

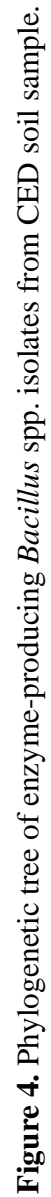




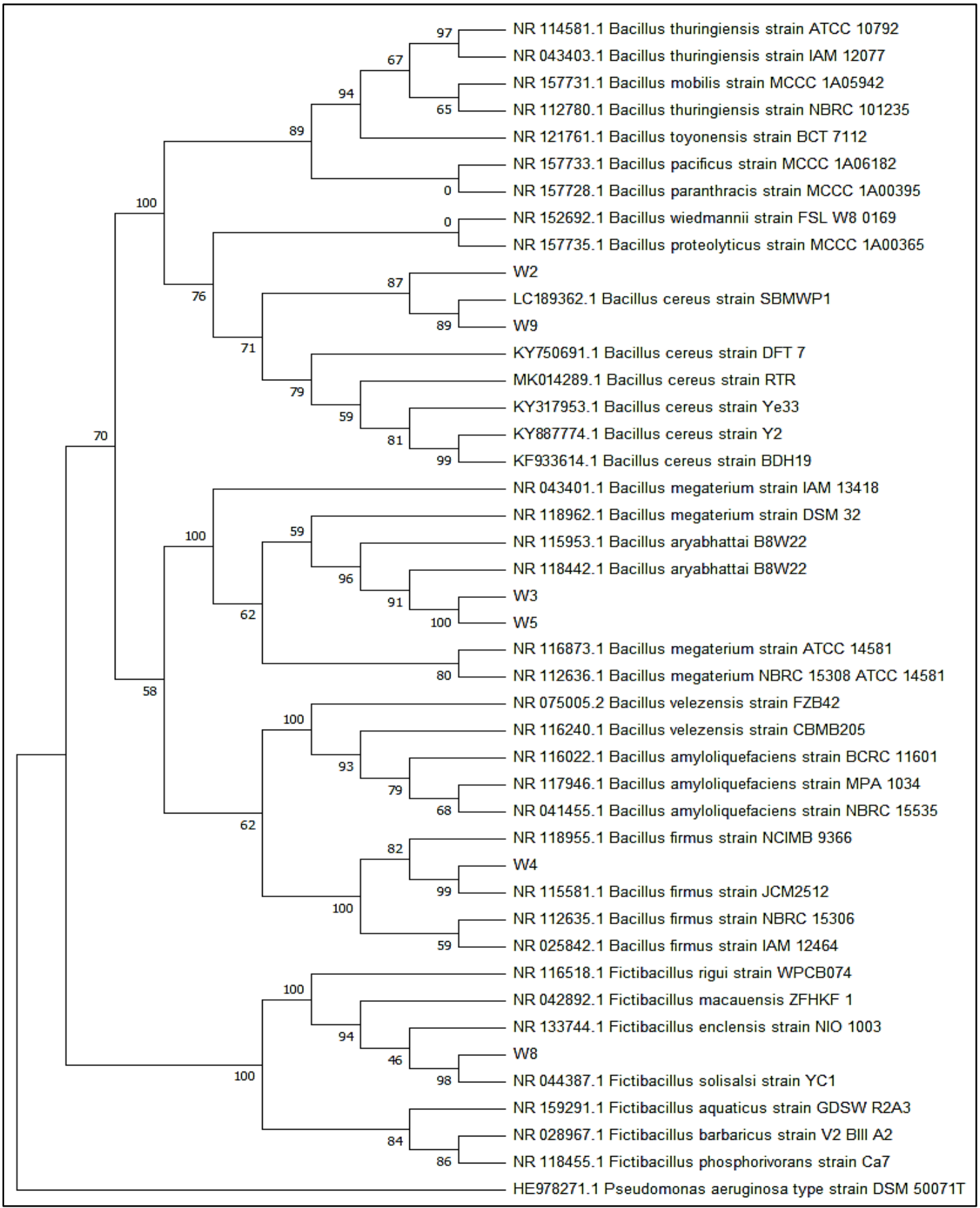

Figure 5. Phylogenetic tree of Bacillus spp. isolates from NML soil sample.

nonetheless, it has been previously shown to produce protease $^{19-20}$.

This study may be the first to report $B$. aryabhattai isolates from the Philippines capable of producing protease.

Isolate W4 from NML soil sample, identified as $B$. firmus, was also observed to produce protease. Previously, a novel Sep1 protein from B. firmus has been characterized as a serine protease capable of degrading the intestinal tissue and cuticle of nematodes ${ }^{21}$. Similarly, a protease-producing strain of $B$. firmus has also been isolated from soil and used to optimize the production of the enzyme relative to the effects of temperature, $\mathrm{pH}$, and salinity ${ }^{22}$. This study also reports the isolation of Fictibacillus sp. (thought to be a putative Bacillus spp. isolate) from NML soil sample which produces protease (Figure 4). An earlier study which was able to isolate Fictibacillus sp. from rhizosphere has also reported its capability to produce protease ${ }^{23}$. Furthermore, a proteaseproducing strain of $B$. velezensis was isolated from CRK1 soil (Figure 6). B. velezensis associated with plants ${ }^{24-25}$ and a strain isolated from manure ${ }^{26}$ have also been shown to produce protease. Its presence in the CRK1 sample may be attributed to its potential tolerance to the edaphic conditions. A paper has previously reported a heavy metal-tolerant protease from a $B$. velezensis strain 


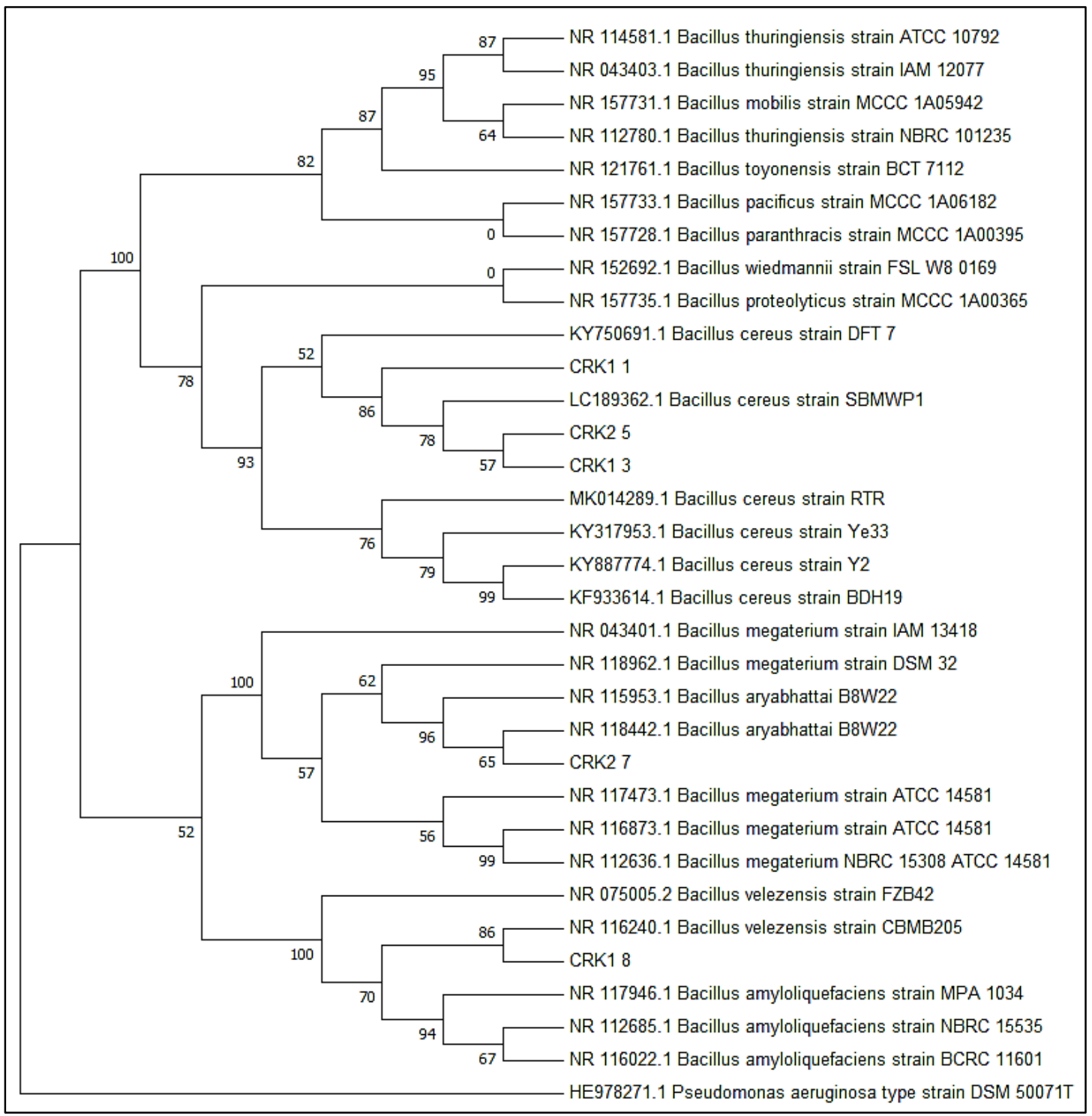

Figure 6. Phylogenetic tree of Bacillus spp. isolates from CRK soil samples.

isolated from the rhizosphere of tomato plant ${ }^{27}$.

These results show the potential of urban soil as a source of industrially-important enzymes. It may be inferred that drastic changes in the environmental conditions, such as those resulting from volcanic eruptions, might affect the enzyme production of these microorganisms. By performing an in-depth phenotypic and genotypic characterization of the enzymes produced by these isolates, we may come up with a better understanding of their activities. Moreover, genetic modification tools may also be used in further applying this information in the mass production of these enzymes. Thereafter, their application for a wide variety of uses, especially those in the pharmaceutical industry, may be tapped.

\section{CONCLUSIONS}

Changes in the environment, particularly as a result of urbanization and volcanic eruptions, drastically alter the edaphic conditions, soil microbial ecology, and enzymatic activities. This work showed the diversity in terms of the species present in the different metropolitan and metropolitan-volcanic samples, as well as their corresponding enzymatic activities. It reported the ability of locally-isolated Bacillus spp. to produce amylase and protease. Interestingly, it was also observed that no isolate was able to produce amylase alone. Overall, these results suggest the potential use of these native isolates in the production of pharmaceutically-important enzymes.

\section{ACKNOWLEDGEMENT}

This project is funded by the Industrial Technology Development Institute through its 2019 General Fund. The authors would like to acknowledge the help of Mr. Melvin R. Razon throughout the conduct of the study; Mr. Arrjay Mar B. Rivera and Ms. Christienne Capsa for their help in the collection of soil samples and conduct of molecular assays. 


\section{Conflict of interest}

The authors declare no conflicts of interest.

\section{Funding}

This project is funded by the Industrial Technology Development Institute through its 2019 General Fund.

\section{Ethics approval}

None to declare.

\section{Article info:}

Received August 12, 2021

Received in revised form December 8, 2021

Accepted January 17, 2022

\section{REFERENCES}

1. Alves PD, Siqueira Fde F, Facchin S, Horta CC, Victória JM, Kalapothakis E. Survey of Microbial Enzymes in Soil, Water, and Plant Microenvironments. Open Microbiol J. 2014;8(1): 25-31.

2. Corrêa TLR, Moutinho SK dos S, Martins MLL, Martins MA. Simultaneous $\alpha$-amylase and protease production by the soil bacterium Bacillus sp. SMIA-2 under submerged culture using whey protein concentrate and corn steep liquor: compatibility of enzymes with commercial detergents. Food Sci Technol. 2011; 31(4):843-8.

3. Tuysuz E, Gonul-Baltaci N, Omeroglu MA, Adiguzel A, Taskin M, Ozkan H. Co-production of Amylase and Protease by Locally Isolated Thermophilic Bacterium Anoxybacillus rupiensis T2 in Sterile and Non-sterile Media Using Waste Potato Peels as Substrate. Waste and Biomass Valorization. 2020;11(12):6793-802.

4. Liu L, Liu Y, Shin HD, Chen RR, Wang NS, Li J, et al. Developing Bacillus spp. as a cell factory for production of microbial enzymes and industrially important biochemicals in the context of systems and synthetic biology. Appl Microbiol Biotechnol. 2013;97(14):6113-27.

5. Razzaq A, Shamsi S, Ali A, Ali Q, Sajjad M, Malik A, et al. Microbial proteases applications. Front Bioeng Biotechnol. 2019; 7:1-20.

6. de Souza PM, de Oliveira Magalhães P. Application of microbial $\alpha$-amylase in industry-a review. Braz J Microbiol. 2010;41(4): 850-61.

7. Burns RG, DeForest JL, Marxsen J, Sinsabaugh RL, Stromberger ME, Wallenstein MD, et al. Soil enzymes in a changing environment: Current knowledge and future directions. Soil Biol Biochem. 2013;58:216-34.

8. Shi ZJ, Lu Y, Xu ZG, Fu SL. Enzyme activities of urban soils under different land use in the Shenzhen city, China. Plant Soil Environ. 2008;54(8):341-6.

9. Ma Q, Han L, Zhang J, Zhang Y, Lang Q, Li F, et al. Environmental risk assessment of metals in the volcanic soil of Changbai mountain. Int J Environ Res Public Health. 2019;16(11):2047.

10. Aponte H, Meli P, Butler B, Paolini J, Matus F, Merino C, et al. Meta-analysis of heavy metal effects on soil enzyme activities. Sci Total Environ. 2020;737:139744.

11. Hedreyda CT, Monsalud RG. Species identification of thermotolerant Bacillus isolates using 16s rDNA, gyraseB Gene (gyrB) and enzyme gene sequence analysis. Philipp J Sci. 2017;146(4): 361-9.

12. Murthy S, Bali G, Sarangi S. Biosorption of Lead by Bacillus cereus Isolated from Industrial Effluents. Br Biotechnol J. 2012; 2(2):73-84.

13. Syed S, Chinthala P. Heavy Metal Detoxification by Different Bacillus Species Isolated from Solar Salterns. Scientifica (Cairo). 2015;2015:1-8.
14. Prakash M, Banik RM, Koch-Brandt C. Purification and characterization of Bacillus cereus protease suitable for detergent industry. Appl Biochem Biotechnol. 2005;127(3):143-55.

15. Sundararajan S, Kannan CN, Chittibabu S. Alkaline protease from Bacillus cereus VITSN04: Potential application as a dehairing agent. J Biosci Bioeng. 2011;111(2):128-33.

16. Saleem M, Rehman A, Yasmin R, Munir B. Biochemical analysis and investigation on the prospective applications of alkaline protease from a Bacillus cereus strain. Mol Biol Rep. 2012;39 (6):6399-408.

17. Shivaji S, Chaturvedi P, Begum Z, Pindi PK, Manorama R, Padmanaban DA, et al. Janibacter hoylei sp. nov., Bacillus isronensis sp. nov. and Bacillus aryabhattai sp. nov., isolated from cryotubes used for collecting air from the upper atmosphere. Int J Syst Evol Microbiol. 2009;59(12):2977-86.

18. Bhattacharyya C, Bakshi U, Mallick I, Mukherji S, Bera B, Ghosh A. Genome-guided insights into the plant growth promotion capabilities of the physiologically versatile Bacillus aryabhattai strain AB211. Front Microbiol. 2017;8:1-16.

19. Adetunji AI, Olaniran AO. Statistical modelling and optimization of protease production by an autochthonous Bacillus aryabhattai Ab15-ES: A response surface methodology approach. Biocatal Agric Biotechnol. 2020;24:101528.

20. Pathak AP, Rathod MG, Mahabole MP, Khairnar RS. Enhanced catalytic activity of Bacillus aryabhattai $\mathrm{P} 1$ protease by modulation with nanoactivator. Heliyon. 2020;6(6):e04053.

21. Geng C, Nie X, Tang Z, Zhang Y, Lin J, Sun M, et al. A novel serine protease, Sep1, from Bacillus firmus DS-1 has nematicidal activity and degrades multiple intestinal-associated nematode proteins. Sci Rep. 2016;6:1-12.

22. Rao K, Narasu ML. Alkaline protease from Bacillus firmus 7728. African J Biotechnol. 2007;6(21):2493-6.

23. Chen Y, Wang W, Zhou D, Jing T, Li K, Zhao Y, et al. Biodegradation of lignocellulosic agricultural residues by a newly isolated Fictibacillus sp. YS-26 improving carbon metabolic properties and functional diversity of the rhizosphere microbial community. Bioresour Technol. 2020;310:123381.

24. Chen L, Gu W, Xu H yan, Yang GL, Shan XF, Chen G, et al. Complete genome sequence of Bacillus velezensis 157 isolated from Eucommia ulmoides with pathogenic bacteria inhibiting and lignocellulolytic enzymes production by SSF. 3 Biotech. 2018;8(2):1-10.

25. Moon JH, Won SJ, Maung CEH, Choi JH, Choi SI, Ajuna HB, et al. Bacillus velezensis ce 100 inhibits root rot diseases (Phytophthora spp.) and promotes growth of japanese cypress (Chamaecyparis obtusa endlicher) seedlings. Microorganisms. 2021; 9(4):821.

26. Khalid A, Ye M, Wei C, Dai B, Yang R, Huang S, et al. Production of $\beta$-glucanase and protease from Bacillus velezensis strain isolated from the manure of piglets. Prep Biochem Biotechnol. 2021;51(5):497-510.

27. Vörös M, Manczinger L, Kredics L, Szekeres A, Shine K, Alharbi NS, et al. Influence of agro-environmental pollutants on a biocontrol strain of Bacillus velezensis. Microbiologyopen. 2019;8(3):1-12. 